\title{
ZONA PERI-URBAN SEMARANG METROPOLITAN: PERKEMBANGAN DAN TIPOLOGI SOSIAL EKONOMI
}

\author{
Peri-Urban Zone of Semarang Metropolitan: Socioeconomic \\ Development and Typology
}

Iwan Rudiarto ${ }^{1}$, Wiwandari Handayani, Bitta Pigawati, Pangi

Diterima : 20 Maret 2013 Disetujui: 31 April 2013

\begin{abstract}
Abstrak: Peri-urban secara umum dapat dipahami sebagai suatu wilayah disekitar perkotaan (pinggiran kota) yang memiliki percampuran karakter antara desa dan kota. Tulisan ini bertujuan untuk mengkaji perkembangan sosial ekonomi dan membuat tipologi Wilayah Peri Urban (WPU) Metropolitan Semarang antara periode waktu 19902011. Wilayah penelitian meliputi 295 desa/kelurahan yang terdistribusi di empat kota dan kabupaten, yaitu; Kota Semarang, Kabupaten Semarang, Kabupaten Kendal, dan Kabupaten Demak yang masuk dalam deliniasi wilayah Metropolitan Semarang. Analisis ini menggunakan analisis overlay, analisis buffer dan distance, dan analisis spasial deskriptif, hasil analisis menunjukkan bahwa metropolitan Semarang telah mengalami perubahan dan pergeseran kondisi sosial ekonomi yang cukup signifikan dari pedesaan ke perkotaan sehingga wilayah desa dan kota tidak bisa dengan mudah didikotomikan. Kebijakan pengembangan wilayah desa dan kota yang terintegrasi merupakan suatu hal penting untuk ditindaklanjuti untuk menciptakan pembangunan keruangan yang lebih seimbang di wilayah Metropolitan Semarang.
\end{abstract}

Kata Kunci: Wilayah peri-urban, Perkembangan Sosial Ekonomi, SIG, Metropolitan Semarang.

\begin{abstract}
Peri-urban can be understood as an area mostly rural located in the surrounding urban center which also has obvious urban character. This paper aims to assess the socioeconomic development of Peri-Urban Areas (PUA) of the Metropolitan Semarang in 19902011. Study area covers 295 villages that are included in the delineation of the Metropolitan area of Semarang. They are distributed in four cities/districts, i.e.: Semarang city, Semarang regency, Kendal regency, and Demak regency. Satellite imaginary analysis and Geographic Information System (GIS) analysis including overlay analysis, buffer and distance analysis, and descriptive spatial analysis were applied for the analysis. The analysis results show that the PUA of metropolitan Semarang has undergone changes and shifts in socioeconomic conditions of rural significant to urban areas. In conclusion, the existence of PUA has led to the blurring of the distinction between rural and urban areas which are not simply dichotomized. Integrated development policies are very essential for more balanced urban development in Semarang Metropolitan region.
\end{abstract}

Keywords: Peri-Urban Area, Socioeconomic Development, GIS, Metropolitan Semarang.

\footnotetext{
${ }^{1}$ Jurusan Perencanaan Wilayah dan Kota, Fakultas Teknik, Universitas Dipoengoro Jl. Prof. Soedhrato, SH - Tembalang Semarang
}

Korespondensi: iwan.rudiarto@undip.ac.id 


\section{Pendahuluan}

Urbanisasi di Asia termasuk di Indonesia memiliki karakter yang berbeda dengan urbanisasi yang terjadi di negara-negara maju di Eropa dan Amerika. Di Asia, urbanisasi sebagai suatu proses transformasi aktifitas manusia dalam konsepsi ruang berimplikasi pada munculnya setidaknya dua fenomena yang saling berkaitan dan tidak secara signifikan terjadi di negara-negara Eropa dan Amerika. Pertama adalah kemunculan wilayah-wilayah mega urban yang kemudian menghadirkan kota-kota primate $^{2}$ (Douglass, 2000).Kemunculan wilayah-wilayah ini mengindikasikan adanya kesenjangan pembangunan yang mengakibatkan ketidakmerataan persebaran penduduk dan aktifitas ekonomi. Fenomena kedua adalah munculnya wilayah periurban yang sangat dominan tersebar di wilayah pinggiran kota yang relatif cepat berkembang. McGee (1991) mengidentifikasi wilayah ini sebagai wilayah desa-kota.

Peri-urban secara umum dapat dipahami sebagai suatu wilayah disekitar perkotaan (pinggiran kota) yang memiliki percampuran karakter antara desa dan kota. Percampuran karakter ini dapat diindikasikan dari pola pemanfaatan lahan, karakteristik demografi, dan ketersediaan atau pelayanan infrastruktur publik. Namun, Allen (2003) dan Laquinta dan Drescher (2000) menyatakan bahwa sebenarnya belum ada definisi peri-urban yang dapat disepakati secara global. Faktanya adalah, wilayah dengan karakter peri-urban juga tumbuh dan berkembang di lokasi yang secara geografis relatif jauh dari wilayah perkotaan walaupun periurban dalam penelitian ini adalah wilayah desa-kota yang berlokasi di pinggiran kota.

Seperti halnya yang terjadi di Metropolitan Semarang, perkembangan kota Metropolitan Semarang telah melingkupi daerah-daerah di pinggiran kotanya (periurban) yang termasuk dalam wilayah administrasi kota/kabupaten lain. Hal ini dianggap relevan karena wilayah peri-urban sangat strategis untuk diarahkan demi terciptanya keseimbangan lingkungan dan pemerataan pembangunan.Fenomena kota primatetelah terjadi dimana jumlah penduduk Kota Semarang sebagai kota metropolitan pada tahun 2010 sudah mencapai lebih dari 1,5 juta jiwa, namun jumlah penduduk perkotaan di sekitarnya kurang dari 100.000 jiwa (Handayani, 2011). Hal ini mengindikasikan adanya konsentrasi pembangunan yang tidak merata yang pada akhirnya berimplikasi pada ketidakseimbangan lingkungan. Fenomena primacy ini juga mengindikasikan kemunculan wilayah peri-urban di sekitar Kota Semarang yang perlu diarahkan untuk mengendalikan ketidakseimbangan yang telah terjadi.

Adanya kecenderungan terjadinya ketimpangan pembangunan yang berpotensi pada terjadinya kerusakan lingkungan karena adanya eksploitasi dan konversi lahan mengarah kepada pentingnya elaborasi secara mendalam terhadap kemunculan wilayah peri-urban di sekitar Kota Semarang. Diharapkan, pemahaman yang mendalam terhadap dinamika yang terjadi di wilayah peri-urban ini dapat membantudalam upaya perumusan formulasi kebijakan perencanaan pembangunan yang berkelanjutan dan perencanaan yang lebih berorientasi pada keseimbangan dan pemerataan.

Tulisan inimerupakan bagian dari hasil penelitian yang dilakukan untuk melihat tipologi zona peri-urban Metropolitan Semarang. Secara khusus, tulisan ini bertujuan untukmengkaji perkembangan sosial ekonomi dan membuat tipologi Wilayah Peri Urban (WPU) Metropolitan Semarang antara periode waktu 1990-2011. Indikator-indikator sosial ekonomi yang digunakan sebagai bahan analisis, nantinya akan memperlihatkan perkembangan dan bentuk tipologi sosial ekonomi zona periurban yang terbentuk.

\footnotetext{
${ }^{2}$ Kota yang memiliki jumlah penduduk jauh melebihi jumlah penduduk kota-kota lain disekitarnya.
} 


\section{Bahan Dan Metoda}

Penelitian zona peri-urban Semarang Metropolitan ini menggunakan pendekatan kuantitatif, dimana semua data dan informasi yang dikumpulkan diolah dan dianalisis secara kuantitatif dengan memanfaatkan teknologi Sistem Informasi Geografis. Mengacu pada judul artikel, maka analisis penelitian yang dilakukan yaitu:

1. Analisis Intensitas Kekotaan

Analisis ini dilakukan dengan tujuan untuk melihat tingkat kekotaan dari suatu wilayah peri-urban berdasarkan indikator sosial ekonomi. Analisis ini akan menghasilkan karakteristik sosial ekonomi desa-kota dari suatu unit wilayah periurban dengan memakai unit analisis per desa.

\section{Analsisi Tipologi Wilayah Peri-Urban}

Sebagai kelanjutan dari analisis tingkat kekotaan, analisis tipologi digunakan dengan tujuan untuk mengklasifikasikan wilayah peri-urban berdasarkan karakteristik sosial ekonomi. Hasil dari analisis tipologi ini adalah berupa pembagian zona transisi dari wilayah peri-urban.Untuk memberikan gambaran sosial ekonomi di wilayah peri-urban, maka analisis spasial deskriptif digunakan.Analisis spasial deskriptif digunakan untuk menggambarkan indikatorindikator sosial ekonomi yang pada akhirnya dapat dijadikan dasar dalam penentuan zona-zona wilayah peri-urban metropolitan Semarang.Gambaran mengenai analisis spasial deskriptif kaitannya dengan zona peri-urban dapat dilihat pada Gambar 1 berikut.

Sumber: Penulis, 2012.

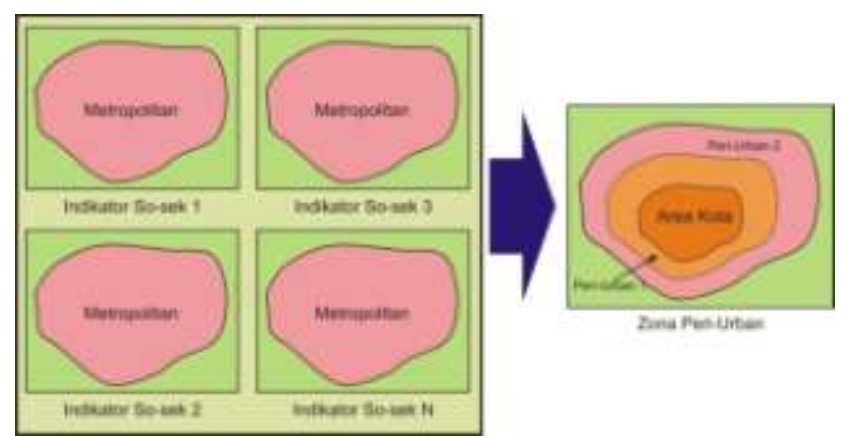

Gambar 1. Tipologi Analisis Spasial Deskiptif

\section{Hasil Dan Pembahasan}

\section{Perkembangan Sosial Ekonomi Metropolitan Semarang}

Perkembangan sosial ekonomi masyarakat wilayah peri-urban pada umumnya akan terpengaruh oleh perkembangan kota inti (urban core). Seperti yang dijelaskan oleh Yunus (2008) bahwa perkembangan kota inti akan berdampak pada transformasi fisik, sosial dan ekonomi dari wilayah peri-urban.

Dalam menganalisis perkembangan sosial ekonomi masyarakat Metropolitan Semarang, diasumsikan bahwa wilayah yang menjadi kota inti dan mampu mempengaruhi perkembangan peri-urban di sekitarnya ternyata memiliki perbedaan antara tahun 1990 dengan tahun 2011, yang menjadi tahun dasar perbandingan perkembangan Metropolitan Semarang. Pada tahun 1990, wilayah yang menjadi kota inti meliputi 3 kecamatan di Kota Semarang, yaitu Kecamatan Semarang Tengah, Ke- 
camatan Semarang Timur, dan Kecamatan Semarang Selatan. Sedangkan untuk tahun 2011, perkembangan terjadi sangat pesat sehingga meliputi 9 kecamatan di Kota Semarang, yaitu: Kecamatan Semarang Tengah, Kecamatan Semarang Timur, Kecamatan Semarang Selatan, Kecamatan Semarang Barat, Kecamatan Semarang Utara, Kecamatan Gayamsari, Kecamatan Gajahmungkur, Kecamatan Pedurungan dan Kecamatan Candisari.

Di samping itu, analisis perkembangan sosial ekonomi Metropolitan Semarang dilakukan dengan mempertimbangkan tiga variabel, yaitu kepadatan penduduk, rasio perempuan terhadap laki-laki, dan proporsi rumah tangga petani.Dilakukan juga proses pengklasifikasian Wilayah Peri Urban (WPU) Metropolitan Semarang ke dalam tiga zona, yaitu peri-urban primer, peri-urban sekunder, dan rural periurban.Penzonaan peri urban ini akan menggunakan tipe zona dari Singh (2011).

\section{Kondisi dan Klasifikasi Kepadatan Penduduk}

Jumlah penduduk Kota Semarang dan wilayah disekitarnya pada tahun 1990 sekitar 1.335.507 jiwa. Jumlah tersebut tersebar dengan pusat kota semarang sebagai wilayah dengan kepadatan tertinggi. Adapun kecamatan yang menjadi pusat kota Semarang pada awal tahun 90-an ini adalah Kecamatan Semarang Tengah, Semarang Selatan dan Semarang Timur. Berikut adalah peta yang menggambarkan kondisi kepadatan kota Semarang dan wilayah disekitarnya
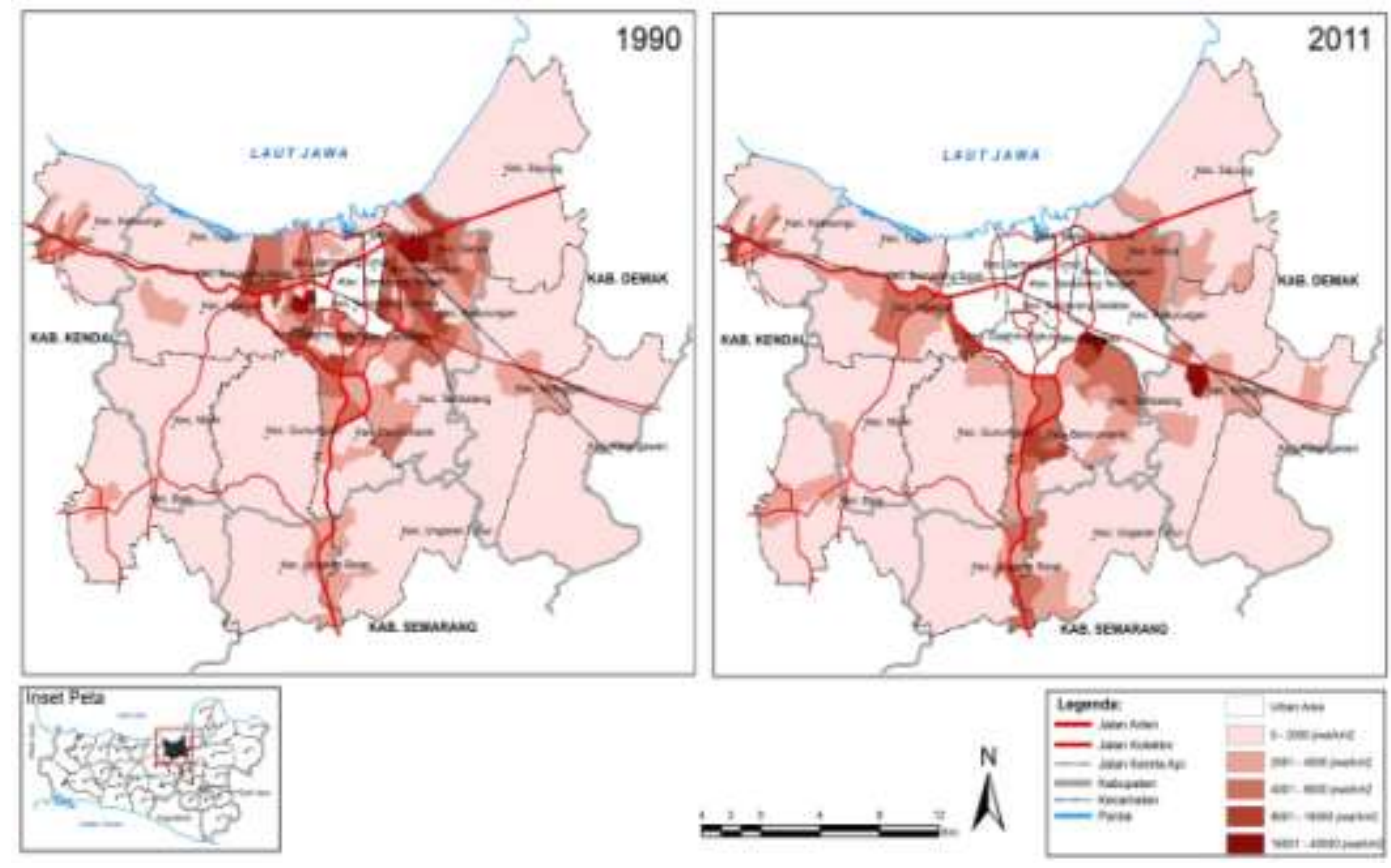

Sumber: Hasil Olahan Peta Dasar pada Tahun 1990 dan 2011

Gambar 2. Peta Kepadatan Penduduk Tahun 1990 dan 2011

Perkembangan Semarang sebagai salah satu kota besar di Indonesia berdampak pada peningkatan kepadatan penduduk di kota tersebut, serta turut mempengaruhi kepadatan penduduk pada daerah yang berbatasan langsung dengan Kota Semarang. Kepadatan penduduk yang tinggi disekitar pusat Kota Semarang pada tahun 
1990 memicu terjadinya perluasan pusat Kota Semarang dari 3 Kecamatan menjadi 9 kecamatan, yaitu Candisari, Gajahmungkur, Gayamsari, Pedurungan, Semarang Barat, Semarang utara dan 3 kecamatan yang sejak awal telah menjadi pusat kota pada Tahun 2011. Adapun pertumbuhan penduduk dari tahun 1990 sampai tahun 2011 dapat dilihat pada gambar 3.

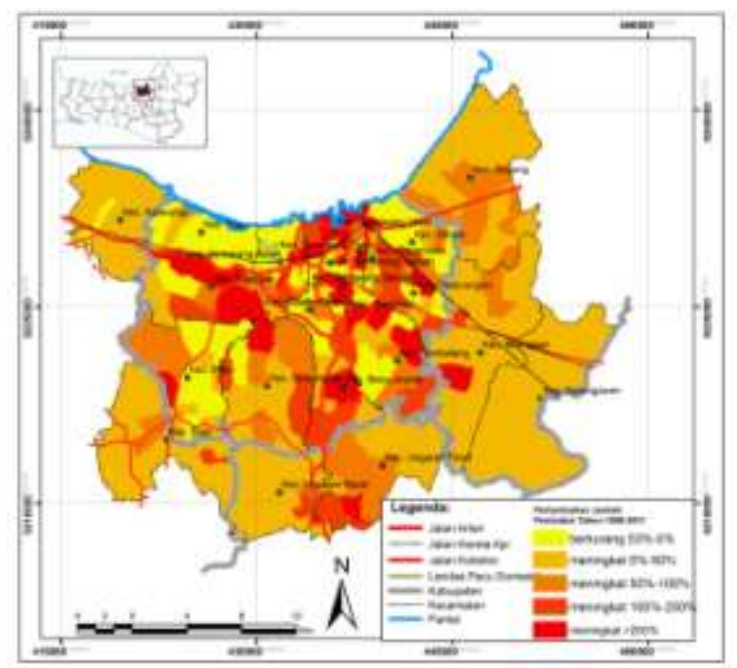

Sumber: Hasil Olahan Peta Dasar pada Tahun 1990 dan 2011

Gambar 3. Peta Pertumbuhan Jumlah Penduduk Tahun 1990 dan 2011

Salah satu faktor yang mempengaruhi pengklasifikasian sifat kekotaan suatu wilayah adalah kepadatan penduduknya.Menurut Singh (2011) dalam pengklasifikasian kepadatan penduduk ini dapat didasarkan pada 3 indikator.Indicator kreteria pengklasifikasian wilayah beradasrkan kepadatan penduduk pada berikut ini:

Tabel 1.Kriteria Klasifikasi Variabel Tingkat Kepadatan Penduduk

\begin{tabular}{ll}
\hline \multicolumn{1}{c}{ Zona WPU } & \multicolumn{1}{c}{ Kriteria } \\
\hline Peri-Urban primer & $\geq 5000 \mathrm{jiwa} / \mathrm{km} 2$ (tingkat desa) \\
Peri-Urban sekunder & $\geq 3000 \mathrm{jiwa} / \mathrm{km} 2$ hingga $<5000 \mathrm{jiwa} / \mathrm{Km} 2$ (desa) \\
Rural Peri-Urban & $\geq 1000 \mathrm{jiwa} / \mathrm{km} 2$ hingga $<3000 \mathrm{jiwa} / \mathrm{km} 2$ (desa) \\
\hline
\end{tabular}

Sumber: Singh, 2011

Melalui penganalisaan data kependudukan pada masing-masing desa di Kota Semarang dan sekitarnya dengan kriteria klasifikasi yang ditunjukan Tabel 1, didapatkan klasifikasi secara spasial terkait zona wilayah peri urban sebagaimana pada gambar 4 . 

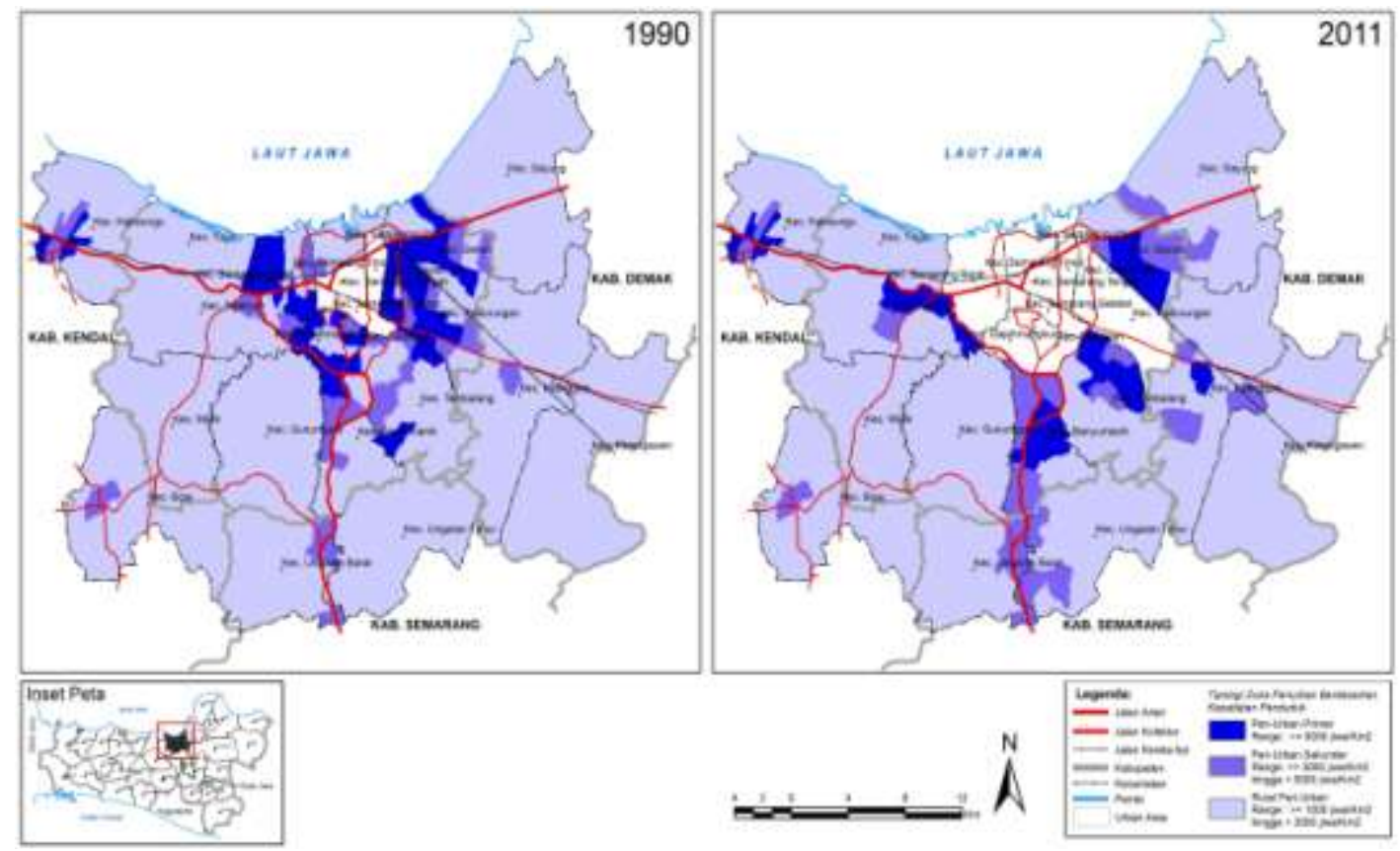

Sumber: Hasil Olahan Peta Dasar pada Tahun 1990 dan 2011

Gambar 4.Peta Klasifikasi Zona Berdasarkan Kepadatan Penduduk Tahun 1990 dan 2011

Dengan kriteria klasifikasi yang ada, pemusatan wilayah klasifikasi urban pada tahun 1990 berada pada semarang bagian pusat dan beberapa terdapat di Kecamatan Kaliwungu, Kendal yaitu Kelurahan Plantaran dan Kutoharjo. Adanya peningkatan jumlah penduduk di wilayah-wilayah tersebut mengakibatkan pergeseran pengkalsifikasian wilayah peri urban berdasarkan kepadatan penduduk.

\section{Rasio Perbandingan Penduduk Laki-Laki dengan Perempuan}

Perkembangan kawasan perkotaan secara spasial merupakan pengaruh dari perubahan sosial kependudukan ataupun sebaliknya. Kondisi kependudukan tersebut salah satunya terkait dengan rasio laki-laki dan perempuan. Rasio jenis kelamin ini dihitung dengan rumus sebagai berikut:

Rasio $=\frac{\text { Jumla } h \text { Perempuan }}{\text { Jumla } h \text { Laki-laki }} \times 1000$

Berikut merupakan peta yang menggambarkan proporsi atau rasio jumlah perempuan terhadap laki-laki. Warna terang menunjukkan proporsi wanita yang lebih sedikit daripada pria. Sebaliknya warna semakin gelap menunjukkan dominasi wanita. 

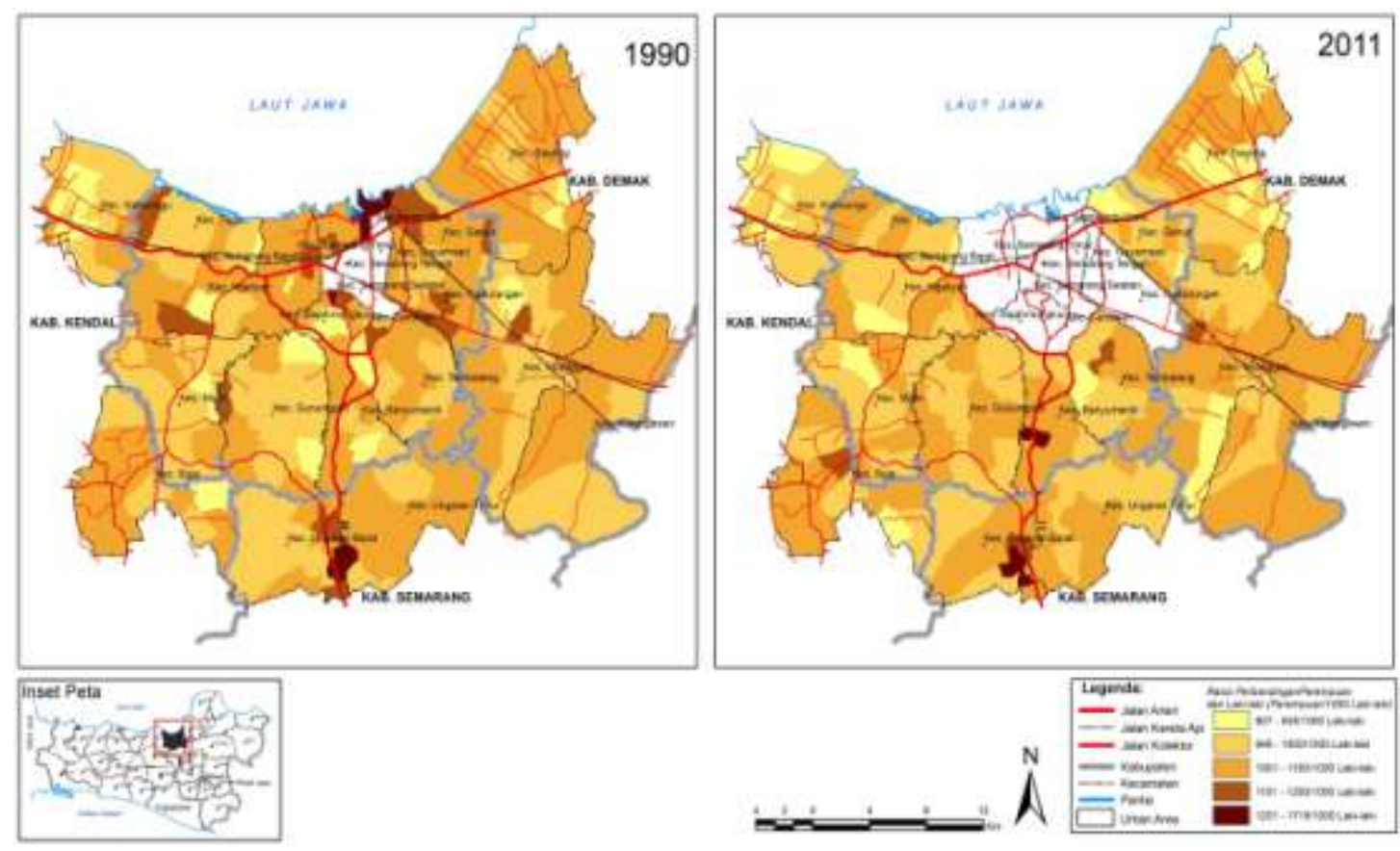

Sumber: Hasil Olahan Peta Dasar pada Tahun 1990 dan 2011

\section{Gambar 5.Peta Proporsi Penduduk Laki-laki terhadap Perempuan Tahun 1990 dan 2011}

Dominasi penduduk laki-laki dan perempuan menunjukkan sifat kekotaan yang didominasi oleh proporsi penduduki laki-laki. Semakin wilayah tersebut berada pada kawasan perkotaan umumnya jumlah penduduk laki-laki semakin meningkat sesuai dengan adanya peluang terbukanya lapangan pekerjaan di pusat kota. Dari peta perkembangan proporsi jenis kelamin, pada wilayah peri-urban Kota Semarang tahun 1990, masih banyak terdapat proporsi laki-laki yang mendominasi, semakin jauh dari pusat kota maka proporsi laki-laki semakin menurun. Akan tetapi pada perkembangannya Tahun 2011, proporsi pria pada pusat kota bertambah. Pada wilayah peri-urban Kota Semarang, proporsi wilayah yang didominasi oleh laki-laki meningkat sesuai dengan perkembangan pusat kota yang semakin melebar.

Untuk mengidentifikasi tingkat kekotaan dari aspek proporsi penduduk perempuan dan laki-laki seperti yang dilakukan oleh Singh (2011) dilakukan klasifikasi zona kekotaanya.Klasifikasi zona berdasarkan jenis kelamin ini adalah dominasi jumlah penduduk laki-laki mengindikasikan suatu zona tersebut dikatakan urban. Hal ini mengasumsikan bahwa daerah urban merupakan daerah yang banyak terdapat lapangan pekerjaan sehingga banyak yang melakukan pekerjaan di sana, dan yang melakukan pekerjaan dianggap sebagian besar adalah laki-laki. Oleh karena itu, semakin banyak jumlah laki-laki pada suatu daerah maka daerah tersebut dianggap sebagai urban atau daerah perkotaan dan sebaliknya.

Klasifikasi zona tersebut dilakukan berdasarkan rasio jumlah penduduk wanita terhadap jumlah penduduk laki-laki.Oleh karena itu, semakin kecil rasio wanita terhadap laki-laki maka semakin daerah tersebut dianggap sebagai urban, dan sebaliknya.Berikut tabel klasifikasi zona berdasarkan rasio jumlah penduduk wanita terhadap pria. 
Tabel 2.Kriteria Klasifikasi Variabel Rasio Jumlah Perempuan terhadap Laki-Laki

\begin{tabular}{lc}
\hline \multicolumn{1}{c}{ Zona WPU } & \multicolumn{1}{c}{ Kriteria } \\
\hline Peri-Urban primer & 751-850 wanita/1000 laki-laki \\
Peri-Urban sekunder & 851-950 wanita/1000 laki-laki \\
Rural Peri-Urban & $\geq 951$ wanita/1000 laki-laki
\end{tabular}

Sumber: Singh, 2011

Dari kriteria klasifikasi yang ditunjukkan pada tabel di atas, maka berikut gambaran secara spasial zona yang terbentuk berdasarkan kriteria tersebut.
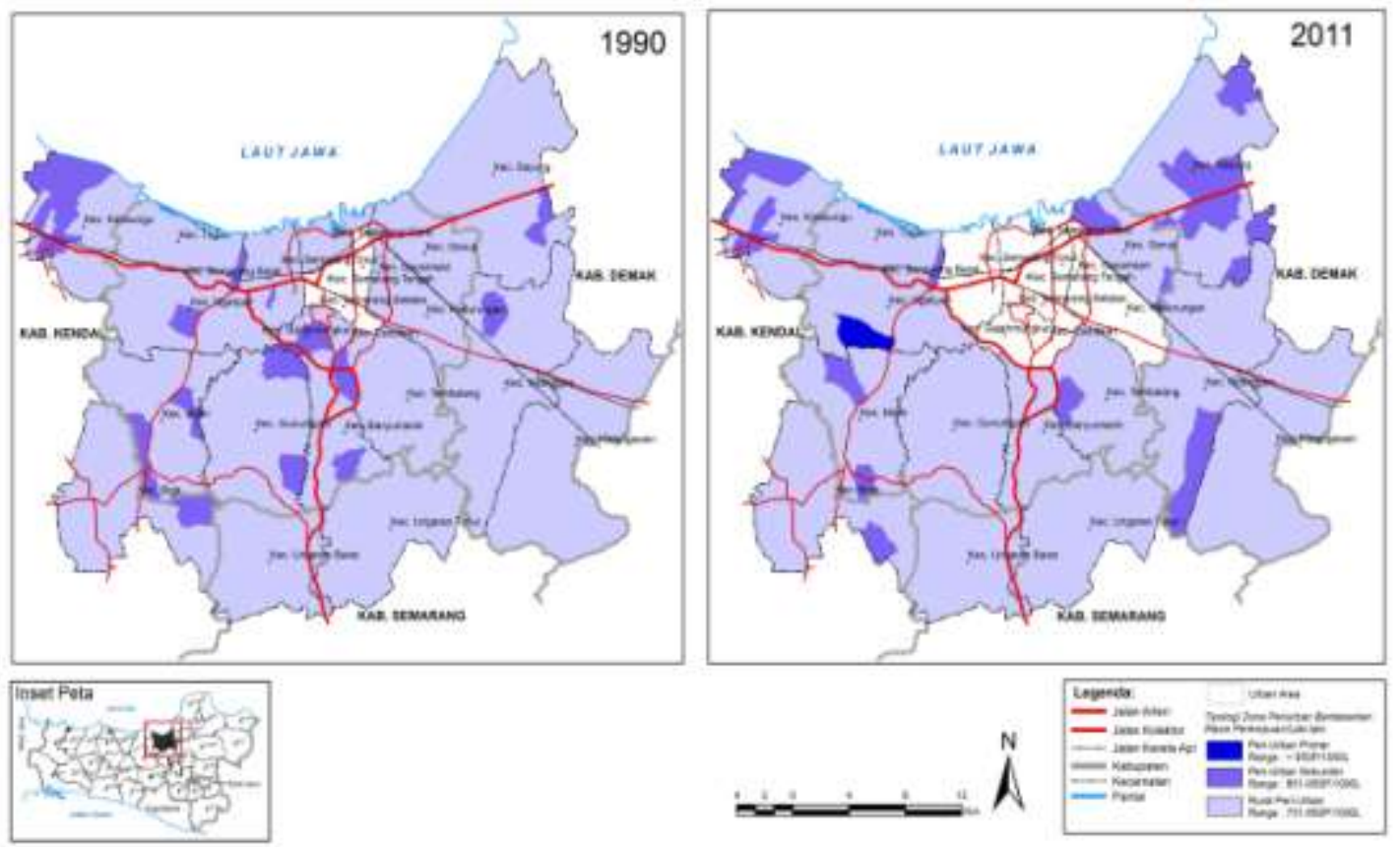

Sumber: Hasil Olahan Peta Dasar pada Tahun 1990 dan 2011

\section{Gambar 6.Peta Klasifikasi Zona Berdasarkan Proporsi Penduduk Laki-laki terhadap Perempuan Tahun 1990 dan 2011}

Pada Tahun 1990, jika melihat dari kriteria yang telah disebutkan pada tabel, tidak terdapat zona urban dimana proporsi pria sangat mendominasi. Oleh karena itu pada tahun tersebut proporsi jumlah wanita terhadap pria hanya ada kategori periurban dan rural-urban.Hal ini dimungkinkan karena pada tahun 1990 kesenjangan atau perbedaan antara kawasan perkotaan dan pedesaan belum begitu terlihat.Hal ini terkait dengan lapangan pekerjaan yang ada di Kota dan sarana prasarana perkotaan penunjang kegiatan.

Pada perkembangannya tahun 2011, terdapat beberapa kelurahan yang berdasarkan kriteria termasuk dalam zona Peri-Urban Primer, yaitu di Ngaliyan yang merupakan pusat perindustrian Kota Semarang.Disamping itu, sebagian kawasan lainnya termasuk dalam zona Peri-Urban Sekunder dimana terdiri dari kecamatan Sayung dan Kecamatan Tugu sebagai pusat kawasan industri.Secara garis besar, Kota Semarang dan sekitarnya, masih didominasi oleh wanita, sehingga pada klasifikasi zona termasuk dalam kategori Peri-Urban Sekunder hingga Rural Peri-Urban. 


\section{Kondisi dan Klasifikasi Penduduk bermata pencaharian sektor pertanian}

Pada sektor ekonomi masyarakat, perihal mata pencaharian penduduk menjadi aspek yang penting.Gambar 7 merupakan gambar yang menunjukkan proporsi rumah tangga bermata pencarian di sektor pertanian yang dibandingkan dengan pekerjaan yang ada. Pada tahun 1990 sektor pertanian menjadi dominasi bagi masyarakat pinggiran sedangkan bagian pusat kota sudah mulai didominasi oleh kegiatan non pertanian.

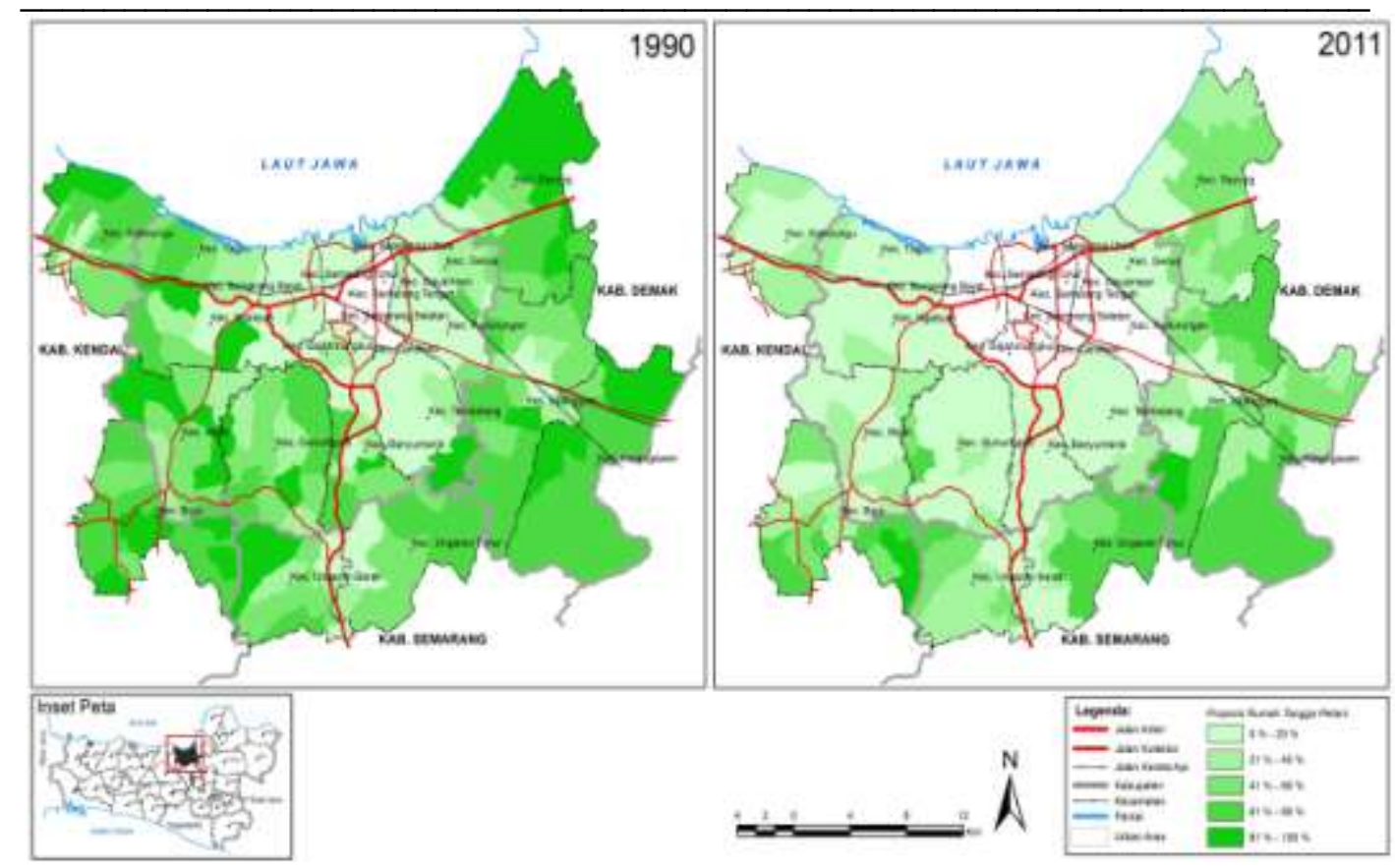

Sumber: Hasil Olahan Peta Dasar pada Tahun 1990 dan 2011

\section{Gambar 7.Peta Proporsi Rumah Tangga Petani dengan Rumah Tangga Total Tahun 1990 dan 2011}

Pada Gambar 7 dapat dilihat mata pencarian dominan masyarakat Metropolitan Semarang dan sekitarnya pada tahun 2011.Perubahan mata pencarian masyarakat turut mengalami pergerakan seiring dengan berkembangnya Kota Semarang. Aktivitas perdagangan dan jasa serta sektor-sektor komersil non pertanian mulai bergerak tidak hanya di pusat kota melainkan berekspansi ke daerah pinggiran. Pada tahun 2011 desa dengan mata pencarian utama disektor pertanian menjadi sangat sedikit.Kota didominasi warna hijau terang yang mewakili proporsi rumah tangga bermata pencarian petani yang rendah.Bahkan terdapat desa/kelurahan yang sudah tidak memiliki aktivitas pertanian.

Variablel mata pencaharian penduduk pada sektor pertanian juga dapat digunakan untuk menentukan zona perkotaan.Klasifikasi pada mata pencaharian sektor pertanian pada wilayah peri-urban dijelaskan oleh Singh (2011) pada Tabel 3 berikut. 
Tabel 3.Kriteria Klasifikasi Variabel Proporsi Rumah Tangga Petani

\begin{tabular}{ll}
\hline Zona WPU & Kriteria \\
\hline \multirow{2}{*}{ Peri-Urban primer } & $\begin{array}{l}20 \%-40 \% \text { penduduk bermata pencaharian sektor } \\
\text { pertanian }\end{array}$ \\
Peri-Urban sekun- & $\begin{array}{l}40 \%-60 \% \text { penduduk bermata pencaharian sektor } \\
\text { pertanian }\end{array}$ \\
Rer & $>60 \%$ penduduk bermata pencaharian sektor \\
Rural Peri-Urban & pertanian
\end{tabular}

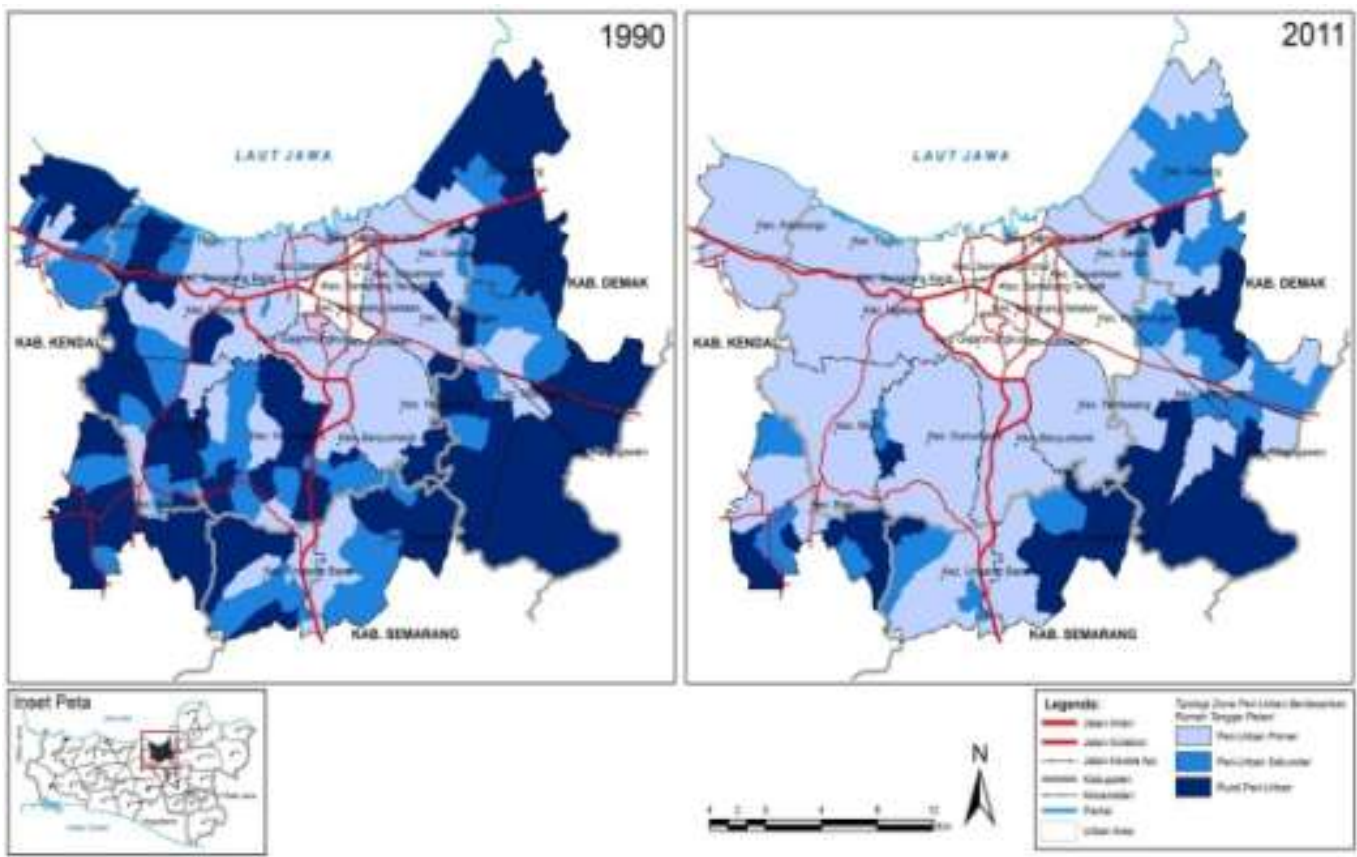

Sumber: Hasil Olahan Peta Dasar pada Tahun 1990 dan 2011

\section{Gambar 8.Peta Klasifikasi Zona berdasarkan Proporsi Rumah Tangga Petani Tahun 1990 dan 2011}

Berdasarkan klasifikasi tersebut maka dapat dibuat zona peri urban yaitu seperti terlihat pada Gambar 8. Kawasan disekitar pusat kota cenderung bersifat kekotaan dengan semakin rendahnya rumah tangga pertanian. Berdasarkan hasil klasifikasi tipologi wilayah Peri-urban Metropoilitan Semarang pada tahun 1990, dominasi rumah tangga petani masih besar pada Kabupaten yang berbatasan langsung dengan Kota Semarang diantaranya Kecamatan Kaliwungu, Kecamatan Boja, Kecamatan Ungaran Timur, Kecamatan Ungaran barat, Kecamatan Mranggen dan Kecamatan Sayung. Identifikasi wilayah sebagai wilayah Peri-Urban Sekunder hingga Rural Peri-Urban mendominasi untuk kawasan yang jauh dari pusat Kota Semarang.

Pada tahun 2011, jumlah keluarga petani menurun sangat drastis.Kondisi tersebut menyebabkan sebagian besar kawasan yang berbatasan langsung dengan Kota Semarang diidentifikasikan sebagai Peri-urban Primer, terutama untuk kecamatan yang letaknya dekat dengan area perkotaan Semarang.Wilayah yang masih teridentifikasi sebagai kawasan Rural Peri-Urban diantaranya adalah sebagian Kecamatan Mranggen dan Kecamatan Sayung. Sedangkan untuk wilayah Kecamatan Kaliwungu dan Kecamatan Boja (Kabupaten Kendal) serta Kecamatan Ungaran Barat 
dan Kecamatan Ungaran Timur (Kabupaten Semarang) lebih bersifat kekotaan dan termasuk dalam zona Peri-Urban Primer.

\section{Tipologi Zona Sosial Ekonomi}

Pengklasifikasian zona pada peri-urban Metropolitan Semarang dilakukan dengan menggunakan metode overlay dan pembobotan. Dengan metode tersebut, maka dalam proses pengklasifikasian zona peri-urban dibutuhkan metode skoring atas hasil klasifikasi dari variabel sosial ekonomi yang telah dilakukan sebelumnya, Tabel 4 menjelaskan bahwa variabel sosial ekonomi yang dipakai, antara lain: kepadatan penduduk, rasio jumlah penduduk perempuan terhadap laki-laki, dan proporsi pekerja sektor pertanian.

Tabel 4. Skoring Klasifikasi Zona Peri-Urban Kota Semarang

\begin{tabular}{|c|c|c|c|c|}
\hline \multirow[b]{2}{*}{ No. } & \multirow[b]{2}{*}{ Variabel } & \multicolumn{3}{|c|}{ Skor } \\
\hline & & Urban & Peri-Urban & Rural Urban \\
\hline 1. & Aspek Sosial & & & \\
\hline$a$ & Kepadatan penduduk & 3 & 2 & 1 \\
\hline $\mathrm{b}$ & Proporsi jumlah wanita & 3 & 2 & 1 \\
\hline 2. & Aspek Ekonomi & & & \\
\hline a & $\begin{array}{l}\text { Proporsi Mata Pencaharian bidang perta- } \\
\text { nian }\end{array}$ & 3 & 2 & 1 \\
\hline TOTAL & & 9 & 6 & 3 \\
\hline
\end{tabular}

Sumber: Hasil Analisis. 2012

Untuk melihat jangkauan skor di tiap zonanya, perlu dilakukan perhitungan jangkauan dengan menggunakan perhitungan interval kelas, dimana sebelumnya telah diketahui bahwa zona akan diklasifikasikan ke dalam 3 kelas, yaitu zona peri urban primer, zona peri-urban sekunder, dan zona rural peri urban. Pada perhitungan interval kelas terdapat hasil 2. Oleh karena itu, zona peri urban primerakan memiliki skor 7-9, zona peri-urban sekunder5-6, dan zona rural urban 3-4.

Melalui proses klasifikasi yang telah dilakukan, hasil klasifikasi zona zanf terbentuk pada tahun 1990 terdiri dari: zona peri urban primer yang memiliki 38 desa, zona peri-urban sekunder memiliki 99 desa, dan zona rural urban memiliki 121 desa, serta untuk kota intinya terdiri dari 35 desa. Sedangkan, untuk klasifikasi pada tahun 2011 terdiri dari: zona peri urban primer dengan 25 desa, zona peri-urban sekunder memiliki 134 desa, dan zona rural urban dengan 46 desa, sedangkan jumlah desa dalam kota inti sejumlah 90 desa (lihat Gambar 9). Jika dilihat dari jumlah perbandingan antara tahun 1990 dengan tahun 2011, diketahui bahwa jumlah zona peri-urban primer mengalami penurunan sekitar 13 desa. Penurunan ini terjadi sebagai bentuk perkembangan beberapa desa ke tingkat yang lebih tinggi lagi, yaitu tingkat kota inti. 


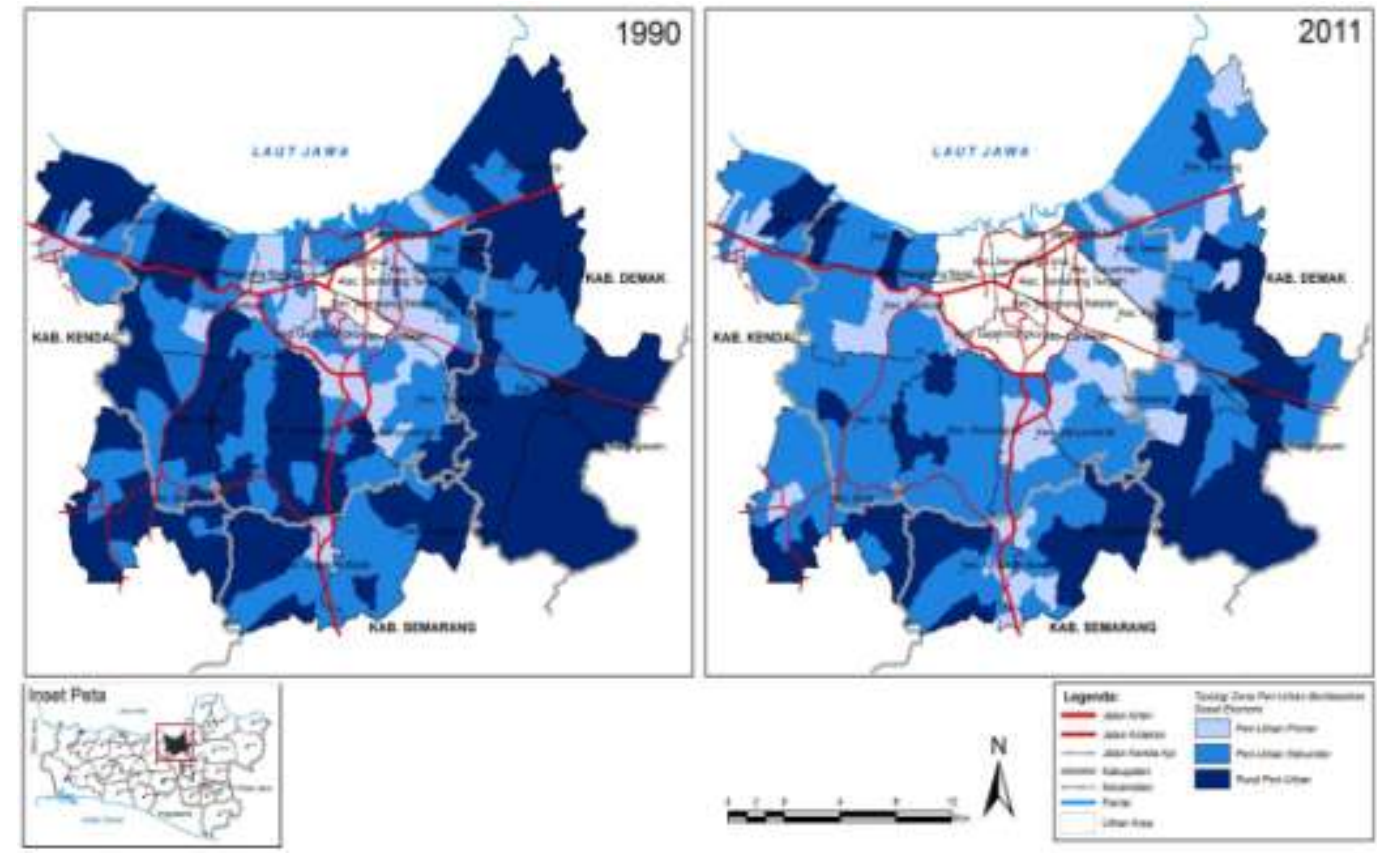

Sumber: Hasil Olahan Peta Dasar pada Tahun 1990 dan 2011

Gambar 9.Peta Klasifikasi Zona Sosial Ekonomi Tahun 1990 dan 2011

Perkembangan jumlah peri-urban sekunder dari 99 desa menjadi 134 desa ternyata mampu mendesak terjadinya penurunan desa-desa yang masuk dalam zona rural peri urban.Dengan demikian, bisa dikatakan bahwa perkembangan sosial ekonomi masyarakat Metropolitan Semarang semakin meningkat ke arah perkotaan. Orientasi aktivitas sosial ekonomi masyarakat pada tahun 1990 yang lebih ke arah sektor pertanian sepertinya mengalami perubahan pada tahun 2011 kepada aktivitas yang lebih bersifat perkotaan yang lebih heterogen. Perkembangan kota inti yang semakin luas juga seperti memberikan jangkauan pengaruh perkotaan yang lebih luas dibanding pada tahun 1990. Dengan demikian, perkembangan peri urban Metropolitan Semarang pada aspek sosial ekonomi semakin meningkat dan bukan tidak mungkin untuk terjadi perubahan ke level perkotaan yang lebih tinggi lagi.

\section{Kesimpulan}

Perkembangankota tidak hanya dapat ditinjau dari unit administrasi tetapi juga pada unit fungsional perkotaan. Salah satu indikator dari berkembangnya suatu kawasan perkotaan adalah aspek social ekonomi kota. Kota Semarang sebagai kota metropolitan mendapatkan tekanan yang cukup signifikan mempengaruhi perubahan penggunaan lahan dan peningkatan jumlah penduduk, sehingga mengalami pemekaran perkotaan atau disebut sebagai ekspansi keruangan (spatial expantion).

Seiring dengan perkembangan tersebut, kepadatan pendudukKota semarangberkembang kearah pinggiran kota (suburbanisasi), yaitu kearah selatan dan kearah timur Kota Semarang. Berdasarkan rasio perempuan terhadap laki-laki, tipologi zona kawasan periurban tidak dapat diidentifikasi karena peran gender dalam pembagian zona tidak terlalu berpengaruh.Berdasarkan aspek ekonomi, rumah tangga petani, periurban Metropolitan Semarang masih banyak terdapat aktivitas pertanian.Hasil overlay karakteristik sosial ekonomi kawasan yang teridentifikasi berubah dari rural peri-urban ke 
periurban sekunder. Berdasarkan perubahan tersebut 99 desa menjadi 134 desa ternyata mampu mendesak terjadinya penurunan desa-desa yang masuk dalam zona rural peri urban.

Ekspansi keruangan perkotaan memunculkan wilayah yang terdefinisi sebagai periurban.Fenomena ekpansi keruangan di negara berkembang berbeda dengan negara maju.Tingkat migrasi perkotaan yang cepat mendorong semakin cepatnya pemekaran ruang perkotaan di negara berkembang.Kondisi tersebut terjadi di Kota Semarangwalaupun dalam konteks yang lebih luas, Kota Semarang bukan sebagai kota yang berkembang pesat seperti Kota Jakarta, Bandung dan Surabaya (Jones, 2002). Tingkat migrasi perkotaan berpengaruh pada perubahan struktur demografi penduduk dan aktivitas perekonomian di wilayah perkotan yang mempengaruhi proses ekspansi keruangannya. Hal tersebut menciptakan adanya wilayah desa dan kota yang tidak bisa dengan mudah didikotomikan. Untuk itu, kebijakan pengembangan wilayah desa dan kota yang terintegrasi merupakan suatu hal penting untuk ditindaklanjuti, sehingga tercipta pembangunan keruangan yang lebih seimbang.

\section{Daftar Pustaka}

Allen, A. 2003. Environmental planning and management of the peri-urban interface:perspective on an emerging field. Environment and Urbanization. 15 (1): 135-148.

Douglass, M. (2000). Mega-urban regions and world city formation: globalization, the economic crisis and urban policy issues in pacific asia. Urban Studies, 37(12), 2315-2335.

Handayani, W, 2011. Emergence of rural-urban regions in Central Java Province: analysis, assessment, and polica recommendations. Götingen: Cuvillier Verlag.

Laquinta, D. L., \& Drescher, A. W. (2000). Defining the peri-urban: rural-urban linkages and institutional connections.Land Reform, 2.

Jones, G. W. (2002). Southeast Asian urbanization and the growth of mega-urban regions.Journal of Population Research, 19(2).

McGee, T. G. (1991). The emergence of desakota regions in Asia: expanding a hypothesis. In N. Ginsburg, B. Koppeö \& T. G. McGee (Eds.), The Extended Metropolis: Settlement Transition in Asia (pp. 3-25). Honolulu: University of Hawai Press.

Singh, Rana P. B. (2011). Changing Rural Landscapes in The Peri-Urban Zone of Varanasi and Strategies for Sustainable Planning. Prosiding International Symposium "Sustainable Rural Landscape and Planning in Asia Pacific Region.IFLA APR Cultural Landscape Committee dan Korean Society of Rural Planning. December $5^{\text {th }}-8^{\text {th }} 2011$. Seoul - Korea Selatan.

Yunus, H. S. (2008).Dinamika Wilayah Peri-Urban Determinan Masa Depan Kota. Yogyakarta:Pustaka Pelajar. 